\title{
Front Matter: Volume 10796
}

, "Front Matter: Volume 10796," Proc. SPIE 10796, Electro-Optical Remote Sensing XII, 1079601 (5 November 2018); doi: 10.1117/12.2517803

SPIE. Event: SPIE Security + Defence, 2018, Berlin, Germany 


\section{PROCEEDINGS OF SPIE}

\section{Electro-Optical Remote Sensing XII}

\section{Gary Kamerman \\ Ove Steinvall \\ Editors}

\section{2-13 September 2018 \\ Berlin, Germany}

Sponsored by

SPIE

Cooperating Organisations

European Optical Society

Cranfield University (United Kingdom)

Published by

SPIE 
The papers in this volume were part of the technical conference cited on the cover and title page. Papers were selected and subject to review by the editors and conference program committee. Some conference presentations may not be available for publication. Additional papers and presentation recordings may be available online in the SPIE Digital Library at SPIEDigitalLibrary.org.

The papers reflect the work and thoughts of the authors and are published herein as submitted. The publisher is not responsible for the validity of the information or for any outcomes resulting from reliance thereon.

Please use the following format to cite material from these proceedings:

Author(s), "Title of Paper," in Electro-Optical Remote Sensing XII, edited by Gary Kamerman, Ove Steinvall, Proceedings of SPIE Vol. 10796 (SPIE, Bellingham, WA, 2018) Seven-digit Article CID Number.

ISSN: 0277-786X

ISSN: 1996-756X (electronic)

ISBN: 9781510621756

ISBN: 9781510621763 (electronic)

Published by

SPIE

P.O. Box 10, Bellingham, Washington 98227-0010 USA

Telephone +1 3606763290 (Pacific Time) · Fax +1 3606471445

SPIE.org

Copyright (C) 2018, Society of Photo-Optical Instrumentation Engineers.

Copying of material in this book for internal or personal use, or for the internal or personal use of specific clients, beyond the fair use provisions granted by the U.S. Copyright Law is authorized by SPIE subject to payment of copying fees. The Transactional Reporting Service base fee for this volume is $\$ 18.00$ per article (or portion thereof), which should be paid directly to the Copyright Clearance Center (CCC), 222 Rosewood Drive, Danvers, MA 01923. Payment may also be made electronically through CCC Online at copyright.com. Other copying for republication, resale, advertising or promotion, or any form of systematic or multiple reproduction of any material in this book is prohibited except with permission in writing from the publisher. The CCC fee code is 0277 $786 \mathrm{X} / 18 / \$ 18.00$.

Printed in the United States of America.

Publication of record for individual papers is online in the SPIE Digital Library.

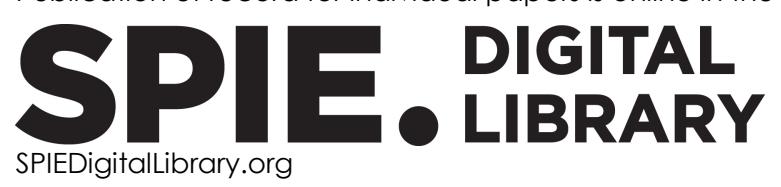

Paper Numbering: Proceedings of SPIE follow an e-First publication model. A unique citation identifier (CID) number is assigned to each article at the time of publication. Utilization of CIDs allows articles to be fully citable as soon as they are published online, and connects the same identifier to all online and print versions of the publication. SPIE uses a seven-digit CID article numbering system structured as follows:

- The first five digits correspond to the SPIE volume number.

- The last two digits indicate publication order within the volume using a Base 36 numbering system employing both numerals and letters. These two-number sets start with 00, 01, 02, 03, $04,05,06,07,08,09,0 A, 0 B \ldots$. OZ, followed by 10-1Z, 20-2Z, etc. The CID Number appears on each page of the manuscript. 


\title{
Contents
}

\author{
$\checkmark \quad$ Authors \\ vii Conference Committee
}

\section{SESSION 1 ACTIVE SENSING I}

1079603 Influence of the obscurants and the illumination wavelengths on a range-gated active imaging system performance [10796-2]

1079604 Mitigation of crosstalk effects in multi-LiDAR configurations [10796-3]

$1079605 \quad$ Novel high-energy short-pulse laser diode source for 3D lidar systems [10796-4]

\section{SESSION $2 \quad$ ACTIVE SENSING II}

1079606 Panoramic single-photon counting 3D lidar (Invited Paper) [10796-5]

1079607 A dual-frequency coherent noise lidar for robust range-Doppler measurements [10796-7]

1079608 Portable bi- $\lambda$ SWIR/NIR gated viewing system for surveillance and security applications [10796-8]

1079609 Shadows in laser imaging and mapping [10796-9]

10796 OA Compressive sensing for active imaging in SWIR spectral range [10796-6]

\section{SESSION $3 \quad$ ACTIVE SENSING III}

10796 OB Software defined multifunction LIDAR (Invited Paper) [10796-10]

$10796 \mathrm{OD}$ Extending the 3D range of a short-wave infrared laser-gated viewing system capable of correlated double sampling [10796-12] 
10796 OE Development of inkjet-deposited test standards for optical sensors [10796-13]

10796 OG Application of nonlinear voxel distribution grid for computational speed-up for linear tomosynthesis reconstruction [10796-36]

\section{SESSION $5 \quad$ SIGNAL PROCESSING}

$10796 \mathrm{OH} \quad$ Computational sensing approaches for enhanced active imaging (Invited Paper) [10796-16]

10796 OJ Error-free coding of range gates for super-resolution three-dimensional imaging [10796-20]

10796 OK Persistent surveillance with small Unmanned Aerial Vehicles (sUAV): a feasibility study [10796-19]

\section{POSTER SESSION}

10796 ON Research and development of a high-energy radiation imaging system based on SiPM and coding aperture [10796-32]

1079600 A novel jamming suppression method for spaceborne multi-channel synthetic aperture radar [10796-25]

10796 OP Robust monocular model-based pose tracking of markerless rigid objects [10796-26]

$107960 Q \quad$ Visual tracker fusion and outlier detection on thermal image sequences [10796-23]

10796 OR Numerical modeling and measurement of polydimethylsiloxane deformation with fiber Bragg grating sensor [10796-28]

10796 OS Application of FBG in the experimental measurements of structural elements deformation from cement composites [10796-29]

10796 OT Deformation sensor composed of fiber Bragg grating and the strain gauge for use in civil engineering [10796-34]

10796 OV Similarity-transform invariant similarity measure for robust template matching [10796-31]

10796 OX Influence analysis of the projection forming method on the reconstruction quality in the digital tomosynthesis [10796-37] 


\title{
Authors
}

Numbers in the index correspond to the last two digits of the seven-digit citation identifier (CID) article numbering system used in Proceedings of SPIE. The first five digits reflect the volume number. Base 36 numbering is employed for the last two digits and indicates the order of articles within the volume. Numbers start with 00, 01, 02, 03, 04, 05, 06, 07, 08, 09, OA, OB...0Z, followed by 10-1Z, 20-2Z, etc.

\author{
Al Nuaimi, Ohood, OK \\ Al Saadi Al Mansoori, Abdullah, OK \\ Alikhanov, A. A., OG \\ Allard, Lars, 06 \\ Almarzooqi, Abdulrahman, OK \\ Almelhi, Omar, OK \\ Apekov, A. M., OG \\ Arens, Michael, 04, OQ \\ Azaña, José, 07 \\ Bacher, Emmanuel, 03, 08, 0J \\ Belyaev, A. O., OG, OX \\ Boldyreff, A. S., 0G, OX \\ Canal, C., 05 \\ Chen, Shengyi, OV \\ Chen, Zhongwei, 00 \\ Christnacher, Frank, 03, 08, 0J \\ Croydon, Matthew J., OB \\ Diehm, Axel L., 04 \\ Dubbs, Amanda, OE \\ Edström, Sten, 09 \\ Emmons, Erik, OE \\ Fajkus, Marcel, OR, OT \\ Fountain, Augustus W., OE \\ Ginter, Joy, OE \\ Göhler, Benjamin, OD \\ Gorbunova, E. B., OG, OX \\ Guicheteau, Jason, OE \\ Hammer, Marcus, 04 \\ Hebel, Marcus, 04 \\ Henriksson, Markus, 06 \\ Hung, Kevin, OE \\ Jia, Mengna, OV \\ Jonsson, Per, 06, 09 \\ Kightley, Peter D., OB \\ Kohl, A., 05 \\ Kovtun, D. G., OG, OX \\ Laugustin, A., 05 \\ Laurenzis, Martin, $08, \mathrm{OH}, 0 \mathrm{~J}$ \\ $\mathrm{Li}$, Xianbin, $0 \mathrm{O}$ \\ Li, Zhang, OP \\ Lin, Xiaohong, 00 \\ Liu, Haibo, OV \\ Liv, Xiaochun, OP \\ Lutz, Y., 08 \\ Lutzmann, Peter, OA, OD \\ Martinek, Radek, OR \\ Mec, Pavel, OR, OS, OT \\ Metzger, N., 03, 08 \\ Moon, Raphael, OE
}

Nedoma, Jan, OR, OT

Novak, Martin, OR, OS, OT

Onori, Daniel, 07

Paunescu, Gabriela, OA

Pinka, Miroslav, OT

Poyet, J.-M., 03, 08

Rabot, O., 05

Roese, Erik, OE

Sayadi, Slim, OK

Scherer-Negenborn, Norbert, $0 Q$

Schertzer, S., 03, 08

Simard, J.-R., 03

Sjökvist, Lars, 09

Steinvall, Ove, 09

Stolarik, Martin, OR, OS

Sun, Cong, OV

Sun, Xiangyi, OV

Swamidoss, Issacniwas, OK

Tang, Xingji, $0 \mathrm{O}$

Thome, Sebastian, $\mathrm{OQ}$

Tripathi, Ashish, OE

Ugolkov, A. V., OG

Vasilev, Aleksandr S., ON

Vasileva, Anna V., ON

Wang, Gang, OP

Wegner, Daniel, OA

Yu, Qifeng, OV

Zabka, Stanislav, OR, OS, OT

Zhang, Hongliang, OP

Zhang, Li, $0 \mathrm{O}$ 
Proc. of SPIE Vol. 10796 1079601-6

Downloaded From: https://www.spiedigitallibrary.org/conference-proceedings-of-spie on 26 Apr 2023 Terms of Use: https://www.spiedigitallibrary.org/terms-of-use 


\title{
Conference Committee
}

\author{
Symposium Chair \\ Ric Schleijpen, TNO Defence, Security and Safety (Netherlands) \\ Symposium Co-chair \\ Karin U. Stein, Fraunhofer-Institut für Optronik, Systemtechnik und \\ Bildauswertung (Germany) \\ Conference Chairs \\ Gary Kamerman, FastMetrix, Inc. (United States) \\ Ove Steinvall, Swedish Defence Research Agency (Sweden) \\ Conference Programme Committee \\ Robert J. Grasso, Polaris Alpha (United States) \\ Laurent Hespel, ONERA (France) \\ Dennis K. Killinger, University of South Florida (United States) \\ Martin Laurenzis, Institut Franco-Allemand de Recherches de Saint-Louis \\ (France) \\ Peter Lutzmann, Fraunhofer-Institut für Optronik, Systemtechnik und \\ Bildauswertung (Germany) \\ Kenneth J. McEwan, Defence Science and Technology Laboratory \\ (United Kingdom) \\ Vasyl Molebny, National Taras Shevchenko University of Kyiv (Ukraine) \\ Philip St John Russell, Max-Planck-Institut für die Physik des Lichts \\ (Germany) \\ Peter N. Randall, QinetiQ Ltd. (United Kingdom) \\ Philippe Réfrégier, Institut Fresnel (France) \\ Gunnar Rustad, Norwegian Defence Research Establishment (Norway) \\ Monte D. Turner, Air Force Research Laboratory (United States)

\section{Session Chairs} \\ 1 Active Sensing I \\ Ove Steinvall, FOI-Swedish Defence Research Agency (Sweden) \\ 2 Active Sensing II \\ Gary W. Kamerman, FastMetrix, Inc. (United States) \\ 3 Active Sensing III \\ Gary W. Kamerman, FastMetrix, Inc. (United States)
}


4 Measurement Techniques

Martin Laurenzis, Institut Franco-Allemand de Recherches de Saint-Louis (France)

5 Signal Processing

Benjamin Göhler, Fraunhofer-Institut für Optronik, Systemtechnik und Bildauswertung (Germany) 